\title{
Globalização, comunicação intercultural e mediações tecnológicas
}

Globalization, intercultural communication, and technological mediation

\author{
Hiliana Reis \\ Profa. Dra. do Departamento de Comunicação da UNISINOS \\ E-mail: hilianareis@uol.com.br
}

1 Parte das questões abordadas neste artigo foram apresentadas no XI Encuentro de Facultades de Comunicación Social (Felafacs) realizado em Porto Rico, outubro de 2003
Resumo

Os efeitos da globalização, aliados aos avanços tecnológicos, abrem um novo campo para o estudo da comunicação intercultural e dos processos de constituição identitária, entendidos não como reprodução de práticas ancestrais, mas como possibilidade permanente de construção de novas coletividades. Diante dos discursos recorrentes sobre os benefícios infindáveis das tecnologias, dos mitos e estereótipos que acompanham essa temática, este artigo pretende oferecer subsídios teórico-metodológicos aos estudos de recepção midiática abordados sob a perspectiva de migrações, novas demandas por competências e constituição de cidadania no contexto latino-americano.

Palavras-chave: globalização, interculturalidade e mídia digital.

Introdução1

As fundamentaçōes teóricas de uma pesquisa que estamos realizando, sobre o uso da mídia digital por estudantes internacionais em duas universidades gaúchas, balizam este artigo alicerçado na ótica dos estudos culturais realizados por Jesús Martín-Barbero, Néstor García Canclini e Miquel Rodrigo Alsina, dentre outros.

O referencial teórico sustenta-se no estudo das mediaçóes que dinamizam as práticas culturais, entendidas como o espaço em que as relaçóes adquirem sentido. O conceito de recepção mediática traz consigo uma dupla conotação: "Refere-se a veículos e instrumentos, mas também às mediaçōes sociais" (Souza, 2000:78). Ao questionar as abordagens anteriores, fragmentadoras e simplificadoras do processo comunicativo, essa abordagem metodológica é de fundamental importância para os pesquisadores que pretendem investigar a complexidade e multiplicidade de fatores que concorrem para o uso e apropriação das ferramentas e produtos midiáticos. Os usuários, como receptores, são, concomitantemente, produtores de sentido. Ao interagirem com textos, sons, imagens e pessoas, criam intertextos, a partir de um repertório compartilhado de representações identitárias coletivas e subjetivas, que dinamiza ou subverte os processos de interação midiáticos. Segundo Jesús Martín-Barbero, as análises de recepção mediática sustentam-se em três proposiçôes: a comunicação é questão de culturas, e não só de ideologias; é questão de sujeitos, e não só de aparatos e estruturas; é questão de produção, e não só de reprodução (Souza, 2000:80).

A cultura é, aqui, entendida como redes de significados compartilhados (Geertz, 1989) que dão sentido às experiências de vida. Os constantes processos de dominação econômica e de intercâmbio cultural, aliados à importância das mídias no mundo contemporâneo, fazem com que as culturas estejam em permanente contato, embora sob diferentes perspectivas. Sem negar a influência dos grupos de referência cultural e familiar que demarcam valores, das expectativas que acompanham os seus membros ao longo da vida, é importante ressaltar que, nas últimas décadas, a mídia passa a ter um papel relevante nesse processo, ao ampliar as fontes de divulgação e acesso às informaçóes, à difusão de valores, concorrendo com a família, a escola, a religião e até com a função anteriormente exercida pelo Estado. Os fluxos de informação veiculados pelos meios de comunicação de massa contribuem para 
modificar os valores, os interesses e os hábitos sociais, influenciando o processo de constituição identitária. A mídia digital, por excelência, amplia essas oportunidades e remete ao conceito de comunicaçăo intercultural.

Miquel Rodrigo Alsina entende a comunicaşão intercultural como aquela que se realiza "entre pessoas que possuem referenciais tão distintos que se autopercebem como pertencentes a culturas diferentes" (1999:12). Assim, o que se produz é um fenômeno de atribuiçäo identitária, em que apenas as diferenças sāo percebidas. Sem negar essa definição, cremos que ela não contempla a diversidade do conceito. $\mathrm{Se}$ as diferenças são evidentes para que se considere como "outra cultura", as semelhanças também são parte constituinte do processo identitário, caso contrário, não haveria espaço para a convivência e o diálogo cultural. Por outra parte, as diferenças sāo evidentes até mesmo nas trocas simbólicas das relações intraculturais, portanto não são categorias específicas das relaçóes interculturais. Analisar a comunicaçāo intercultural apenas sob o ângulo das diferenças, a nosso ver, não contempla a diversidade que as dinâmicas sociais imprimem a esse processo. As análises interculturais necessitam qualificar as experiências na sua concretude para destacar em que as culturas se diferenciam e em que se assemelham.

O papel das mídias, a facilidade de circulação oferecida pelos meios de transporte, ou mesmo o poder aquisitivo que permite o contato direto com outras culturas, contribui para diminuir as diferenças e estreitar as semelhanças culturais não só internas, como também em relação ao exterior. Os formatos da indústria de entretenimento apresentam mais similitudes que diferenças, seja dentro ou fora do país, embora sejam ressignificados por grupos, tribos ou segmentos de classe. Contudo, os processos desencadeados pela globalizaçāo fundamentam-se em fluxos de relaçôes de poder desiguais, o que resulta em formas desiguais de apropriação dos bens simbólicos.
Intercâmbio e redes de culturas

A vivência em outras culturas é um processo instigante e, freqüentemente, desestabilizador dos significados que articulam a constituiçáo identitária dos sujeitos envolvidos, os quais, via de regra, deparam-se com situaçóes desconhecidas, ou até mesmo inusitadas. Exige um realinhamento de comportamentos, negociaçōes de valores e sentidos e, até mesmo, afirmação de outros que, na sua cultura de origem, talvez passassem despercebidos.

Há cinco décadas, o intercâmbio cultural dependia, basicamente, do cruzamento de fronteiras geográficas ou do acesso aos produtos que os meios de comunicaçáo nos propiciavam, em especial o rádio, o cinema, a mídia impressa e, a partir dos anos 50, a televisão. Em curto espaço de tempo, os processos de globalizaçáo, aliados ao desenvolvimento dos recursos tecnológicos, modificaram radicalmente esse cenário, configurando a hegemonia midiática. Ao complementarem-se em infinitas combinaçōes multimediáticas, "os suportes tecnológicos nāo se excluem, ao contrário, se complementam em processos de inter e multirrelacionamentos" (Souza, 2000:77), possibilitando aos seus usuários uma nova maneira de contigüidade, de estarem juntos, de se relacionarem, embora separados no espaço e no tempo. As ilimitadas ofertas de produtos, banco de dados, serviços e ferramentas interativas que circulam pela mídia digital constituem um campo privilegiado para a circulaçāo, produçáo e recepção de novas culturas, em que até mesmo o anonimato abre espaço para novas formas de relaçáa. O universo simbólico que envolve todas as esferas da comunicação humana amplia-se também em face das diferentes modalidades de interaçáo inter e multipessoal que essa mídia potencializa, sendo um excelente recurso para a interlocução entre culturas.

A própria concepção multimidiática e multifacetada das ferramentas e produtos disponibilizados pela mídia digital oferece novas formas de produçáo e recepçáo de mensagens. Multiplicam-se as possibilidades de interação, em que produtores se transformam em receptores e vice-versa,

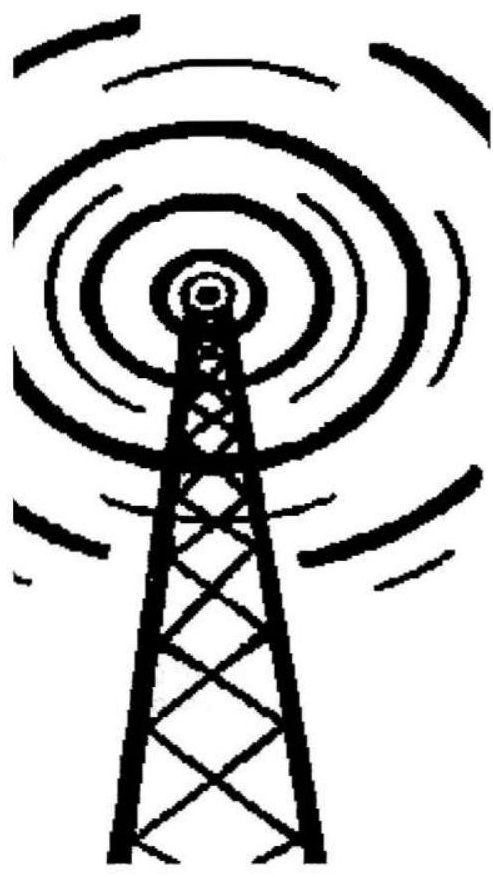


${ }^{2}$ Idioma que congrega a maior parte das informações digitais. desestabilizando a visão unilinear do modelo funcionalista, que dicotomiza produtores e receptores. Sem negar a potencialidade da internet, tanto para acessar informações como para viabilizar e incentivar os processos de comunicação intra e interculturais, cabe aprofundar a discussão sobre a maneira como as pessoas se apropriam dos espaços e produtos ofertados pela rede digital.

Outro fator importante a ser considerado é a inegável facilidade e a capacidade que crianças e jovens experimentam, diante daqueles de mais idade, para explorar as ferramentas e recursos tecnológicos, atribuindo novos significados e usos aos produtos culturais. Entretanto, a singularidade das motivaçôes e necessidades que impulsionam os jovens a utilizar os media, de maneira, inclusive, diferenciada, tem sido pouco explorada pelas pesquisas em Comunicação. Como alerta Blumer, "o ser humano orienta seus atos em funçáo do significado que os objetos adquirem para ele" (Blumer, 1981:2). Tanto nas interaçóes entre sujeito e produto como entre sujeitos, o processo interpretativo é resultante da construção de saberes, cujo processo não caminha na mesma velocidade da oferta do mercado.

Os media abrem uma nova via para a compreensão do lugar por onde se movimentam as identidades culturais, já que oferecem uma infinita gama de interfaces para a busca de informaçăo e de interaçāo comunicativa. Além disso, trazem um valor agregado, já que permitem a circulaçáo de afetos, seduzem ou afastam os usuários, seja pelo conteúdo ou pela formatação. A lógica da produção é uma condição necessária, mas nāo suficiente, para que haja interaçāo. $\mathrm{O}$ amálgama entre as lógicas de produção se faz no cruzamento das lógicas do receptor. As mediaçóes, como lugar de práticas sociais, articulam, desarticulam, criam e recriam as tramas culturais e são fontes de produçāo de sentido. Em vez de polarizarem, aproximam o espaço da produçáo e o da recepção. "Mais do que de meios, a comunicação se faz hoje questão de mediaçōes, isto é, de cultura" (MartínBarbero, 1989:19). A configuração dessas práticas tanto demarcam estruturas como indicam novos caminhos à constituição identitária. A mediação é um lugar de práticas sociais, um processo em permanente construçáo, em que tecnologia e cultura associam-se como espaços de relação e produção de significados.

\section{Processos de exclusão na América Latina}

Apesar de as mídias proporcionarem o aumento da visibilidade das culturas, sejam nacionais ou internacionais e sob os mais variados vieses, a apropriaçăo desses elementos não acontece de maneira uniforme. A democratização do acesso aos bens simbólicos na América Latina acompanha a perversidade do modelo econômico, excluindo uma parte considerável da sua população não só do acesso às tecnologias como, sobretudo, da aquisição das competências para acessá-las. As competências cognitivas, tecnológicas e de interação intercultural, por exemplo, o domínio do inglês ${ }^{2}$, estão restritas a uma pequena parcela da populaçáo global. As diferenças de uso, inclusive, incidem em questóes de gênero e faixa etária.

O uso das tecnologias de informaçāo e comunicação requer novas habilidades cognitivas, reforça a importância dos processos comunicacionais e dos estudos culturais. Entretanto, diante aos mitos que acompanham a temática, é importante recordar que não se trata apenas de novas habilidades. Os processos de exclusáo social interferem nas maneiras de usos e apropriaçóes das tecnologias. Tivemos a oportunidade de observar, em uma pesquisa que realizamos com adolescentes em situação de risco, que aqueles que estavam no segundo grau, e, portanto, tinham o raciocínio abstrato mais desenvolvido, apresentavam melhor desempenho no uso de tabelas do que os que estavam nas primeiras séries do curso básico, ainda que tivessem a mesma idade.

Para complementar, pesquisas realizadas em universidades virtuais (Reis, 2000) certificam que a competência para se comunicar por escrito é um fator-chave para o êxito de seus estudantes. Já que não contam com o apoio da linguagem oral ou gestual, os que escrevem de maneira clara e 
objetiva possuem um handicap de entrada. Outros itens, assinalados na mesma pesquisa, sāo a percepção e a sensibilidade dos parceiros, vistos como fatores de grande satisfação e de aproximação entre alunos e tutores de universidades virtuais. Acreditamos que esses elementos também interferem nas relaçóes que se estabelecem nos chats e nos correios eletrônicos.

Emoção e sentimento são partes constituintes dos processos de produção e construção de significado. A sensibilidade tanto pode estabelecer pontes para a abertura de novas vias de conhecimento como também pode ser fonte de ruptura ao desestabilizar normas e regras préestabelecidas. A produçāo de afetos é um manancial que modifica as estruturas dos ambientes virtuais, abre espaço para o inesperado, para produçóes que envolvem o imaginário coletivo. E este, por sua vez, nos remete novamente ao conceito de cultura, já que o imaginário une passado e presente, e oferece elementos para a compreensão de padróes que orientam as práticas coletivas, atuando, inclusive, como fonte de formação de estereótipos no que se refere à percepção do "outro".

\section{Fluxos migratórios}

Os fluxos de migração são tão antigos quanto a humanidade. Entretanto, modificam-se as causas desses movimentos, que sâo identificadas como políticas, econômicas e sociais. Essas causas também incidem nas sociedades de acolhida, que, muitas vezes, requerem a presença de estrangeiros e, em outras situaçóes, os marginalizam ou, até mesmo, os hostilizam.

Aliados a esse contexto, não apenas as graves crises desestabilizam a economia dos países do Terceiro Mundo, mas a fragilidade dos estados-naçāo inaugura uma nova onda de migraçōes, sobretudo entre os jovens, atraídos pela qualificação profissional ou por salários mais atraentes. Por outro lado, o desejo de viver novas experiências interculturais transforma a América Latina num território privilegiado. A sua diversidade cultural e, inclusive, as matérias pautadas pela mídia internacional apelam aos desejos inconscientes de jovens de outras regióes, associando esse território ao exotismo, à aventura e ao imprevisível. Até mesmo as desigualdades sociais costumam atrair muitos jovens que buscam dar um sentido de solidariedade às suas açóes, como tivemos a oportunidade de observar em trabalhos comunitários. Enfim, é um continente fértil para a proliferação de mitos e estereótipos.

Algumas pesquisas realizadas na década de 60 (Apud Juliano, 1998:127) relacionavam as interaçōes que se produzem na sociedade de chegada com aquelas que motivaram a saída. Da mesma forma, Pellegrino e outros (Apud Juliano, 1998:127) estabeleciam diferença entre os que saíam de seu lugar de origem, obrigados pelas condiçóes do lugar de vida, sem um projeto pessoal, e os que o faziam por uma motivação individual, a fim de melhorar as condiçóes de vida, inexistentes no lugar de nascimento (Juliano, 1998:127). Essas abordagens propiciaram uma tipologia dos imigrantes, classificados como colonizadores, exilados ou refugiados políticos e econômicos. O imigrante econômico é definido como "alguém que opta, com a intenção de melhorar de vida, por viver numa sociedade diferente da

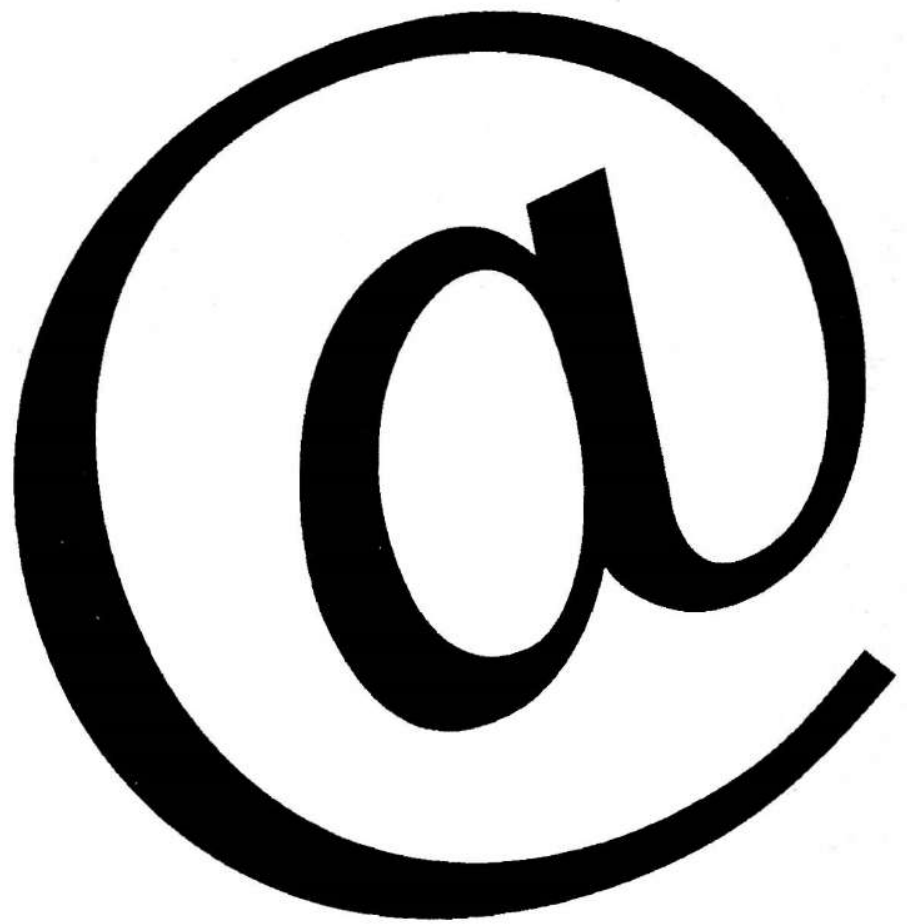




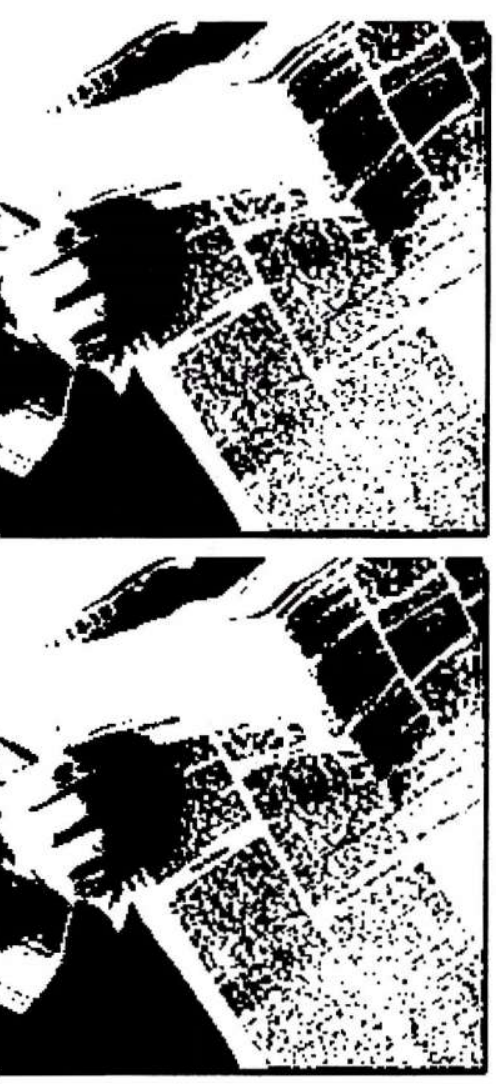

própria, onde não conta com a força nem com a proteção legal. Normalmente, compreende que tem que se adaptar ao novo contexto e está disposto a fazê-lo" (Juliano, 1998:129).

Ainda que essa temática esteja bastante debatida, não contempla a amostra que estamos analisando. Consideramos esses éstudantes como migrantes temporários, motivados por um projeto de vida pessoal de qualificação acadêmica, portanto, profissional. Embora estejam circunscritos a um fluxo migratório, que é temporário, estão respaldados por acordos internacionais celebrados entre o Ministério de Relaçóes Exteriores/MEC ou institucionais. Possuem visto de permanência temporário, renovável a cada ano, direito à assistência médica e permissão para abrir conta bancária no país. Dessa forma, não se inscrevem na categoria descrita anteriormente, desprovida de proteção legal. Como estrangeiros, diferenciam-se de um turista ou de um profissional que se deslocam para outro país por curto prazo de tempo. Estudar em outro país significa afastar-se de seu local e cultura de origem, conviver com novos padróes de vida, criar novos laços de amizade e redes de apoio, por um período de tempo prédeterminado, o que, evidentemente, modifica as formas de inserção cultural.

Por outro lado, embora tenham compromisso de voltar ao local de origem, alguns desses estudantes acabam ficando no país hospedeiro ou encontrando novas oportunidades de estudo em países do primeiro mundo, que oferecem melhores condiçōes de vida e trabalho, e que, em alguns casos, configuram o que se denomina como "fugas de cérebros". O fenômeno migratório, hoje, não pode ser explicado apenas por questő́es econômicas ou políticas. Diante das dinâmicas da sociedade globalizada, as questóes sociais e culturais e de formação profissional também precisam ser contempladas. As constantes crises econômicas que assolam alguns dos países vizinhos, a proximidade geográfica, o interesse pela pesquisa desenvolvida no país, pela formação acadêmica e até pela aprendizagem do português são fatores que contribuem para o aumento da imigração e do interesse pelo Brasil, por parte, sobretudo, de africanos e latino-americanos, dentre os quais se destacam argentinos, uruguaios, bolivianos e paraguaios.

No caso dos estudantes que compóem a amostra da nossa atual pesquisa, já que a vinda ao Brasil parte de projeto pessoal, podemos estabelecer um paralelo com pesquisas anteriores e partir do pressuposto de que esses estudantes são mais permeáveis a novos códigos e sensíveis a adaptar-se ao novo contexto. Entretanto, por maior que seja a empatia diante da sociedade que os acolhe, conservam códigos de comunicaçāo e valores da sua cultura, a partir dos quais estabelecem relaçóes e negociam com a cultura local, o que implica estranhamentos, tensōes e dificuldades.

A proliferação de recursos e ferramentas telemáticas e as políticas de expansão ao seu acesso, ainda que tímidas, já se fazem sentir e favorecem um outro tipo de migraçāo: os migrantes translocais, que não necessitam locomover-se para obter dados, interagir e participar de diferentes situaçóes, relacionar-se com os mais variados rincóes e criar redes de interesses, discussōes e amizades por todo o planeta.

Mercado de trabalho e universo acadêmico

Paralelamente, no contexto globalizado, as novidades impostas pela teleinformática ao mundo do trabalho estão obrigando as empresas a reformularem suas estratégias de gestão. A competição cada vez mais acirrada do mercado de trabalho contribui para a formaçāo de núcleos empresariais regionais e internacionais, em que se mesclam formas de pensar, sentir e fazer diferenciadas, obrigando os profissionais a uma permanente reciclagem. A cada ano, $10 \%$ dos postos de trabalho desaparecem e são substituídos por outros em novas empresas, que requerem novas e mais sofisticadas competências. Há um desprezo pelas habilidades tradicionais e um déficit entre oferta e demanda de novos saberes ${ }^{3}$. Diante desse cenário, não se pode ignorar as 
alternativas que oferecem as transformaçōes produzidas pela sociedade de informaçăo e sequer as barreiras que impóem ao convívio e à sobrevivência humana. Desenvolvem-se novos mecanismos de decisão que favorecem as desigualdades e os antagonismos. "O que se desenvolvia em âmbito local ou nacional, hoje se regionaliza ou mundializa, ampliando as suas conseqüências em proporção geométrica" (Reis, 2000:76). Como afirma Octavio Ianni (1995:113), a emergência da sociedade global abre novas perspectivas aos indivíduos, grupos, etnias e minorias, mas sua transformação realiza-se de modo contraditório, criativo e destrutivo.

$\mathrm{Na}$ tentativa de acompanhar as mudanças requeridas pela sociedade da informação, as empresas passam a investir em um novo perfil profissional, o que aumentou significativamente $o$ interesse pelos estudos de nível superior e o intercâmbio universitário. Ao mesmo tempo, sensíveis às dinâmicas culturais e aos processos comunicativos, as universidades se dão conta de que o intercâmbio e a convivência multiculturais são uma prerrogativa da globalizaçâo. $\mathrm{Na}$ Uniāo Européia, por exemplo, há uma série de programas diferenciados que contemplam a mobilidade e a imersão de professores e alunos em outros países e culturas (Reis, 2000, capítulo 3). Sob esse mesmo enfoque, outro exemplo interessante é o da Hogeschool van Utrecht/CETIS (Holanda), que oferece cursos de capacitação empresarial (MBA), por meio do ensino a distância, com a colaboração de setores governamentais e industriais. As divergências causadas pela diversidade cultural de seus alunos, holandeses, asiáticos e alemães, despertaram a atenção da equipe responsável pela sua implantação, que criou uma metodologia de ensino fundamentada nos processos de comunicaçāo e interação. O método fundamentado na resolução de problemas exige que os participantes interajam constantemente entre si, resolvam conflitos oriundos de diferentes perspectivas culturais e aprendam a negociar com formas de pensamento diferentes, quando

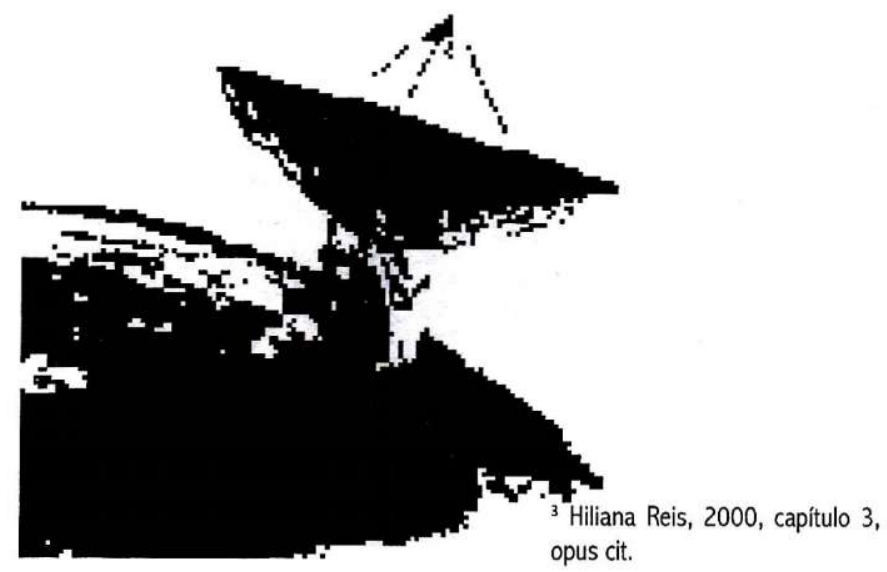

${ }^{4}$ Hiliana Reis, 2000: 158-159.

não, conflitantes ${ }^{4}$. Os desafios da globalização demandam profissionais que tenham capacidade para trabalhar de maneira colaborativa, intercultural e para compreender as diferenças de significação geradas pela multiplicidade de práticas culturais.

\section{Processos e desafios da globalização}

$\mathrm{O}$ início do século XXI vem acompanhado de uma série de rupturas, crises econômicas e históricas, cujas transformaçóes e incertezas afetam o cotidiano das relaçōes sociais, independentemente de onde nos encontrarmos. A globalização da economia e da comunicação diminui o poder anteriormente ocupado pelo Estado-Nação e suas implicaçốes extrapolam as esferas econômico-jurídicas e ampliam-se ao domínio social. As trocas simbólicas, sobretudo com a multiplicação das ofertas pelas mídias, adquirem um novo estatuto e modificam-se as fontes de referência anteriormente ocupadas pela família, escola e religião. Outro aspecto a ser considerado é o poder que a indústria cultural e os valores mercadológicos assumiram nas últimas décadas. Produtividade, competitividade, criatividade, parcerias e 


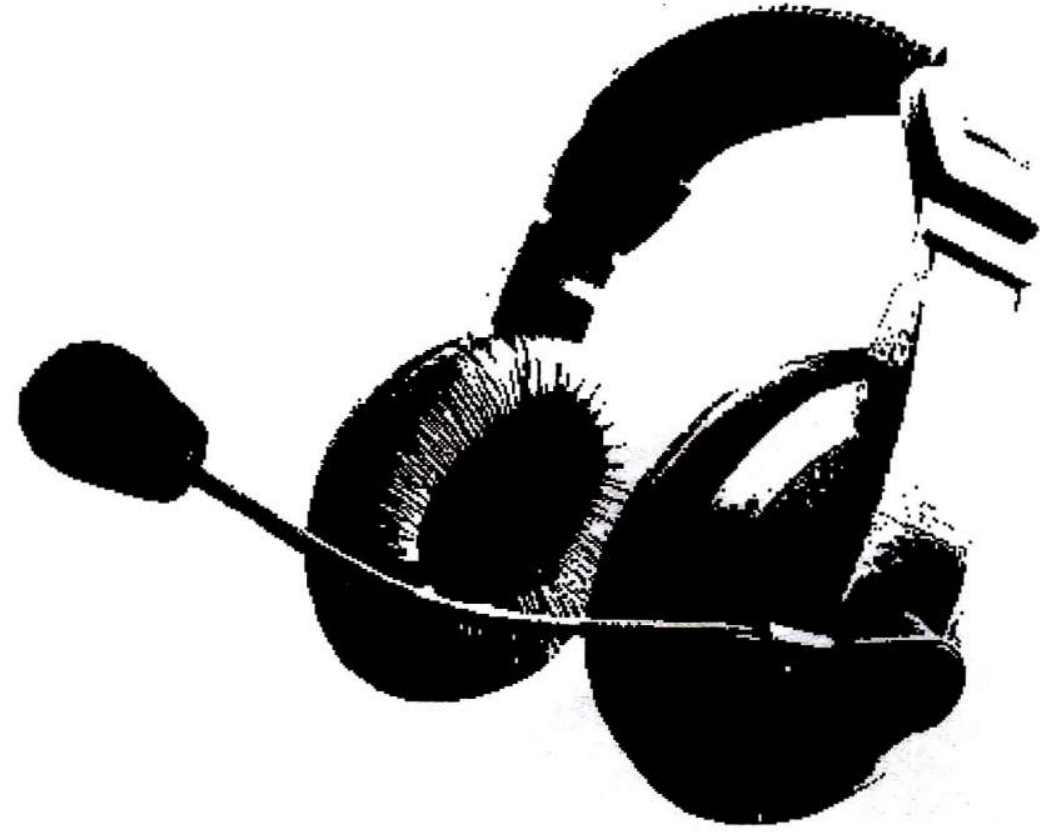

valor agregado sáo conceitos que migraram do setor produtivo para diferentes esferas da vida social, atingindo, inclusive, as instituiçōes universitárias.

Multiplicam-se as parcerias entre empresas de diferentes culturas, as quais requerem novas estruturas, habilidades $\mathrm{e}$ competências. Hoje, o aprender a aprender, a transversalidade e a educaçáo para toda a vida estão no centro das preocupaçóes de empresários, das instituiçóes de ensino e de um grande contingente de jovens universitários, os quais perderam a antiga estabilidade adquirida com a aquisição do grau de bacharel. Os cursos no estrangeiro e a imersão em outras culturas ganham uma nova perspectiva para atender às necessidades e constantes mudanças impostas pela sociedade globalizada. Paralelamente, a necessidade de sobrevivência e a busca de profissionais qualificados em diversos setores têm propiciado uma nova onda de migraçóes internas e externas, impondo mudanças significativas aos contextos culturais. Apesar disso, vale recordar que as condiçōes para a aquisição do conhecimento na sociedade atual ainda são privilégio das elites e das naçóes mais desenvolvidas. Nos países do Terceiro Mundo, que congregam os maiores índices de analfabetismo e de extrema pobreza, seria ingenuidade falar de democratização da informação e dos benefícios da tecnologia. Outros fatores necessitam ser agregados às análises de comunicação mediática.
Ivan Illich, pensador e precursor do movimento antiglobalização, ao mesmo tempo que reconhecia a importância das ferramentas tecnológicas para o bem-estar da humanidade, denunciava o modelo industrial adotado pela sociedade globalizada, cuja maior preocupação voltase à produçāo de bens e serviços, reduzindo as formas de interação social à categoria de consumidores-usuários (IHU, 2002), desconectados da realidade social. Para polemizar essa temática, recordamos que algumas análises de recepção mediática, realizadas por consagrados autores latinoamericanos, relativizam a noção de simulacro e indicam o consumo como lugar de diferenciação social, de demarcaçăo das diferenças, de circulação de sentidos e de distinção simbólica (Martín-Barbero, 2000). Entretanto, não podemos fechar os olhos para a controvérsia que o tema suscita, pois, como recorda García Canclini, "tanto o espaço cultural latino-americano como o euroamericano e o interamericano são multiculturais" (1998:17). E tanto as controvérsias como as convergências não permitem categorizá-los em uma identidade comum. Faz-se necessário analisar tanto as diferenças de uso como de acesso aos bens simbólicos, que imprimem diferentes tonalidades às formas de exclusão social a que está relegada uma grande parte da população mundial.

A pós-modernidade coloca em questão o conceito iluminista que supunha a identidade como um núcleo fixo, constituinte da essência do ser, e os enfoques das análises culturais apresentam diferentes tendências. Enquanto alguns estudos de Néstor García Canclini se detêm na análise dos aspectos da hibridização das culturas, a partir dos fluxos migratórios, Hall, Semprini e Renato Ortiz abordam a desintegraçăo das identidades culturais, articulando a temática dos fluxos culturais entre as naçōes à interdependência e ao modelo mercadólogico de consumo global, o que produz "a fragmentação de códigos culturais, multiplicidade de estilos, ênfase no efêmero, no flutuante, no impermanente, na diferença e no pluralismo" (Semprini, 1999:73-74). 
As dimensôes territoriais do Brasil, a mescla de culturas aliadas às diferenças de acesso aos bens culturais - fruto da injusta distribuiçāo de renda - favorecem a disparidade de comportamentos, de acesso e de competência para o uso das tecnologias. Paralelamente, os preconceitos e os estereótipos que mantemos no cotidiano e os exportamos, sobretudo pelas mídias, contribuem para ocultar a verdadeira dimensão e compreensão dos mecanismos que mobilizam os processos interculturais no cotidiano das relaçôes sociais. Na América Latina, sobretudo, o estudo das lógicas que sustentam as práticas sociais latino-americanas pressupōe "um mundo de significaçóes imediatamente ligado ao das desigualdades sociais" (Souza, 2000:83).

Deixar de lado as certezas que nos movem é a primeira premissa que se impóe aos pesquisadores que lidam com fenômenos culturais, sobretudo na América Latina, marcada pelas desigualdades de acesso aos bens econômicos e, conseqüentemente, aos culturais. Somos uma cultura marcada pela mestiçagem, sincretismo e hibridização cultural que, ao mesmo tempo, mantêm diferenças locais, regionais e étnicas.

Embora o fenômeno da globalização contribua para homogeneizar a oferta de produtos culturais, as comunidades imprimem marcas subjetivas, como atestam as pesquisas de recepção mediática (Souza, Lopes, Orozco Gómez). Entre os indicadores dessas diferenças destacam-se classe, gênero, idade, nacionalidade e grau de instruçāo. Outro fator muito importante a ser considerado é a sensibilidade dos usuários para lidar com as diferenças culturais - que imprimem novos significados aos processos de interação intersubjetivos - realizados por meio das mídias digitais 5 .

Os sujeitos são marcados pelo seu contexto cultural e as apropriaçóes do conhecimento não são neutras nem se realizam num vazio. Jung e Geertz demonstram que a memória humana é seletiva e coletiva, e, nesse sentido, a cultura atua como elemento estruturante dos processos cognitivos. A interiorização de elementos proporcionados por uma determinada cultura demarca pontos de convergência e de fuga do que se depreende de um cenário. À medida que salienta alguns aspectos, outros são colocados à sombra, já que não são suscetíveis de significação. Não só os hábitos perceptivos e verbais variam de cultura para cultura, como também os princípios de seletividade variam de pessoa para pessoa.

As pessoas agem motivadas por crenças, desejos, intençōes e valores, alimentos das "redes de expectativas mútuas" (Bruner, 1995:163). O autor salienta que a observaçäo do outro depende de como o vemos: amigo, inimigo, rival, desconhecido, e o que os sujeitos dizem depende de como os participantes interpretam a relaçáo entre quem faz a pergunta ou proposiçáo e quem a responde (Bruner, 1995:110). Embora circunscrita a outro âmbito, pesquisa realizada com tutores e alunos de universidades virtuais demonstrou que respostas insatisfatórias, impositivas ou indelicadas desestimulam os processos de interação virtual (Reis, 2000). Ao assumir que os media desempenham um importante papel nas dinâmicas de transformação cultural, esta pesquisa também não elimina a premissa de que as matrizes da cultura de origem preservam certos valores, os quais demarcam as escolhas e preferências. Nas dinâmicas de interaçâao comunicativa, realizadas por meio da mídia digital, entram em jogo as preferências individuais, a sensibilidade e as competências dos interlocutores, além das lógicas das ferramentas, que impedem ou convidam os usuários a utilizá-las ou abandoná-las. São, portanto, inúmeros os fatores que apontam para a exclusão social e para os desafios que se colocam aos governos, sociedade, movimentos sociais, ONGs e educadores.

\section{Algumas consideraçóes}

Em face das temáticas aqui abordadas, um dos grandes desafios que o fenômeno da globalização coloca aos pesquisadores da Comunicação é a compreensáo das dinâmicas que movem as interaçóes interculturais no universo da 
mídia digital. As mudanças no cenário comunicativo não nos permitem ficar à margem desse processo vertiginoso que, a cada dia, lança novos produtos no mercado e proclama a democratização da informação, como se esse processo fosse independente dos usos e apropriaçôes que os usuários tecem na intrincada rede de tramas inter e intraculturais, dos segmentos de classe, de gênero e de competências cognitivas, linguísticas e tecnológicas. Os fatores psicológicos, a sensibilidade das pessoas e a ética também tomam relevo nos diferentes processos que as ferramentas e produtos tecnológicos possibilitam. A mídia digital é uma fonte fecunda para os estudos culturais abordados sob a perspectiva da recepção mediática, via por onde transitam diferentes conhecimentos, dos quais as pessoas se apropriam com os mais variados interesses e, também, por onde se afirmam e se recriam as identidades. Ao permitir o reforço de valores e identidades culturais, a mídia digital amplia as possibilidades de hibridização de identidades, mediante a proliferação de redes de apoio e de informaçốes em que são negociadas novas atribuiçóes de sentido.

No espaço multicultural que configura a América Latina, o acesso desigual aos bens culturais e à produçāo do conhecimento tem implicaçóes e sérias conseqüências sociais nos usos e apropriação dos espaços midiáticos. A tecnologia é condição suficiente, mas não necessária, para a mudança cultural, uma vez que os processos de interação realizados por meio da mídia digital são mediados, simultaneamente, pelos conteúdos disponibilizados em rede, pelas lógicas das ferramentas, mas também pelas competências cognitivas, lingüísticas e tecnológicas dos usuários.

A democratizaçāo das informações nāo se reduz à sua disponibilização. No momento em que as universidades estão passando por um processo de renovação dos modelos de gestão e buscando adequarse às necessidades de transformação que a sociedade requer, precisam levar em conta as possibilidades abertas pela mídia digital, que coloca em interação diferentes interesses e setores sociais, e a necessidade de formação de quadros universitários que compreendam a importância dos processos de significação cultural dos atores que imprimem novas marcas e direcionamentos aos processos de interação intercultural. À preocupação pela oferta de cursos para a formaçāo de elites pensantes, pelos cursos de reciclagem, ou até mesmo de profissionalização, precisa-se contrapor a necessidade de estender os benefícios da globalização aos setores marginalizados e semimarginalizados da sociedade. Descobrir novas oportunidades de interação e novos modelos de convivência torna-se imperativo neste novo milênio, em que não são poucas as vozes a conclamarem o fim da civilizaçăo.

\section{Abstract}

The effects of globalization along with technological advances open new avenues for the study of intercultural communication and of identity constitution processes. Such processes are understood here as permanent possibilities for the construction of new colectivities, in opposition to their interpretation as the reproduction of ancestors practices. Contradicting current discourses that attribute endless benefits to technologies, myths, and stereotypes constantly reaffirmed by the media regarding technology, this paper aims at providing theoretical and methodological foundations for the study of media reception under an approach focused on migration, competencies, and citizenship constitution in the Latin American context.

Key words: globalization, interculturality, and digital media.

\section{Bibliografia}

ALSINA, Miquel Rodrigo. La comunicación intercultural. Barcelona, Antropos, 1999.

BLUMER, Herbert. El interaccionismo simbólico. Barcelona, Hora, 1981.

BRUNER, Jerome. Actos de Significado. Más allá de la revolución cognitiva. Madrid, Alianza. 1995. 
IANNI, Octavio. A sociedade global. Rio de Janeiro, Civilização Brasileira, 1995.

ILLICHT, Ivan. Ivan Illicht: pensador radical e inovador. In: IHU-OnLine. São Leopoldo, Unisinos, Ano 2, no 46, 9 de dezembro de 2002, pp. 1-9.

GARCÍA CANCLINI, Néstor. La Globalización Imaginada. México, Paidós, 1999.

GEERTZ, Clifford. A Interpretação das Culturas. Rio de Janeiro, Editora Guanabara, 1989.

HALL, Stuart. Quem precisa da identidade? In: Identidade e diferença. A perspectiva dos estudos culturais. Petrópolis, Vozes, 2000, pág. 103-133.

JULIANO, Dolores. Inmigrantes de segunda. La adscripición étnica asignada. In: Santamaría, E. y González, F. Contra el fundamentalismo escolar. Reflexiones sobre educación, escolarización y diversidad cultural. Barcelona, Virus Editorial, 1998. LOPES, Maria Immacolata Vassalo de; BORELLI, Silvia H. S; RESENDE, Vera da Rocha. Vivendo com a telenovela: mediaçóes, recepção e teleficcionalidade. São Paulo, Summus, 2002.

MARTÍN-BARBERO, Jesús. Cidade Virtual: novos cenários da comunicação. In: Comunicaçāo \& Educação. São Paulo, ECA/USP, ano IV, n¹1, jan/abril, 1998. MURCIANO, Marcial y REIS, Hiliana. Sociedade de informação: políticas da Uniāo Européia. In: Comunicaçâo \& Educação. São Paulo, ECA/USP, ano VII, n० 20, jan/abril, 2001, p. 63-74.

OROZCO GÓMEZ, Guillermo. Educación, medios de difusión y generación de conocimientos hacia una pedagogía crítica de la representación. In: Nómadas. Santafé de Bogotá, Fundación Universidad Central, no 5, pp. 23-30, 1994.

REIS, Hiliana. Ampliación de los procesos comunicativos en la enseñanza a distancia: análisis de tres modelos de tutoría. Tese de Doutorado, Universitat Autònoma de Barcelona (UAB), Bellaterra, 2000.

REIS, Hiliana e LOZANO, Fernando. Procesos de interacción comunicativa en la tutoria virtual. Revista de Investigación en Educación. Monterrey, EGE/UVTEC, ano 2 , número 8 , janeiro/fevereiro de 2002, p. 4-16.
SOUZA, Mauro W. Novos cenários no estudo da recepção mediática. In: Eugenio Trivinho (org.) et altri. Sociedade mediática. Significação, mediaçōes e exclusāo, 2000, pág. 77-89.

SEMPRINI, Andréa. Multiculturalismo.

Bauru, Edusc, 1999.

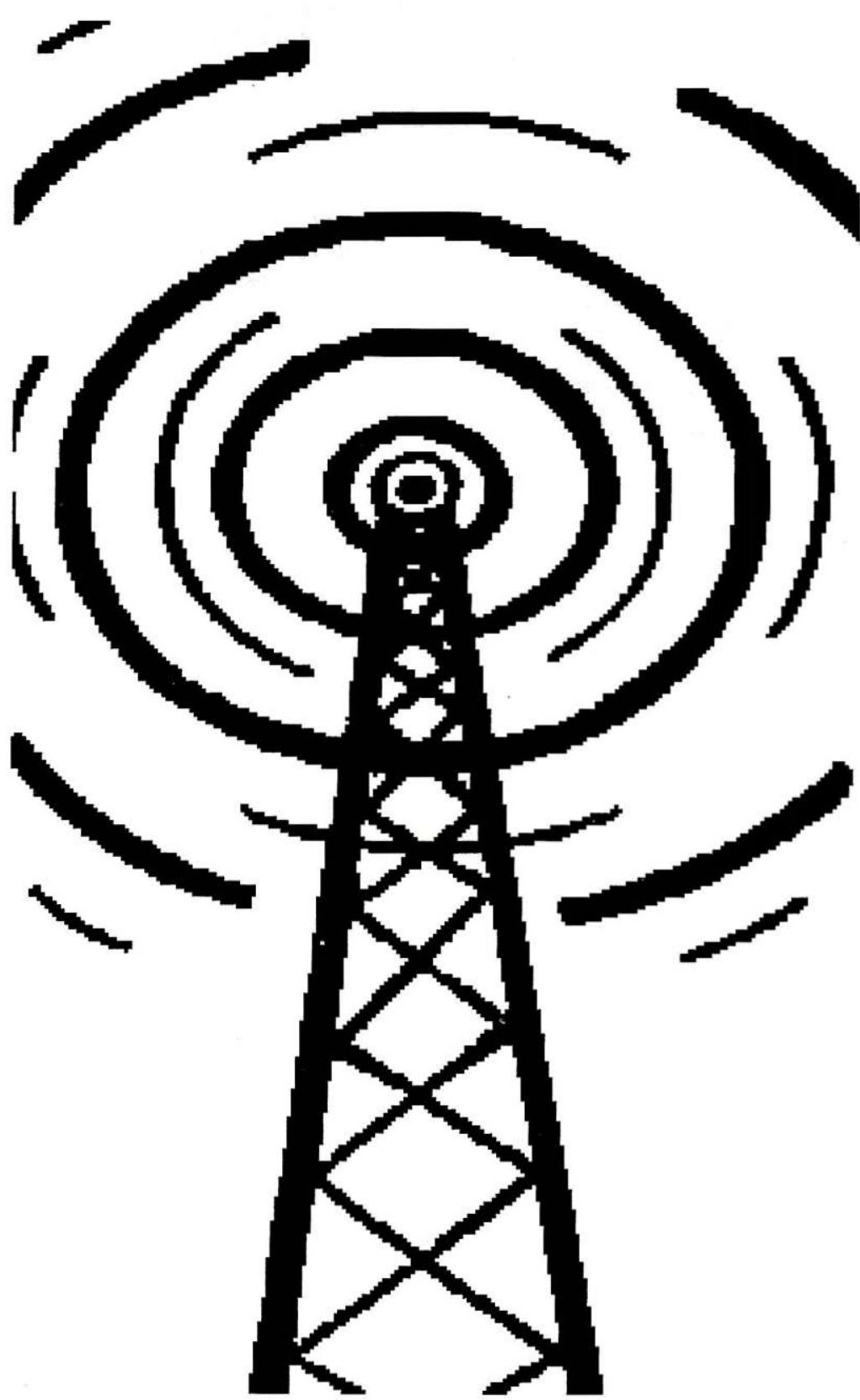

